\title{
LABOR RELATIONS IN NATIONALIZED INDUSTRIES WITH PARTICULAR REFERENCE TO THE COAL MINING INDUSTRY
}

\author{
W. KenNETh GRATwick, M.B.E.*
}

I

\section{InTRODUCTION}

The importance of labor relations in industry, whether nationalized or under private enterprise, cannot be over-emphasized. The human factor is all important and no industry can be expected to prosper unless a firm basis of understanding is secured. Reorganization, new machinery, and other technical improvements will not bring the desired results if labor relations at all levels are not harmonious. The establishment and maintenance of good labor relations call for men of vision and experience in securing cooperation and in the long run much will depend on their handling of this most difficult problem.

II

\section{Conciliation}

One of the first steps in labor relations is to establish conciliation machinery for the settlement of terms and conditions of employment. The various Acts $^{1}$ by which certain industries were placed under public ownership imposed a duty on the management to set up and maintain joint machinery for this purpose. So far as the coal mining industry is concerned the relevant provisions are to be found in Section 46(I) (a) of the Coal Industry Nationalisation Act, 1946, which is in the following terms:

It shall be the duty of the Board [i.e., the National Coal Board set up under the Act] to enter into consultation with organisations appearing to them to represent substantial proportions of the persons in the employment of the Board, or of any class of such persons, as to the Board's concluding with those organisations agreements providing for the establishment and maintenance of joint machinery for the settlement by negotiation of terms and conditions of employment, with provision for reference to arbitration in default of such settlement in such cases as may be determined by or under the agreements. ...

Machinery for dealing with disputes arising out of wages and conditions of employment had been in operation in the coal mining industry at district level for

- Secretary of the Mining Association of Great Britain since March, 1950. Head of the Statistical Branch of the Mining Association of Great Britain, 1936-r946. Senior Director of Labor Relations Department of the National Coal Board, r947-1950.

${ }^{1}$ Civil Aviation Act, 1946, 9 \& ro Gzo. 6, c. 70, $\$ \mathrm{rg}(\mathrm{r})(\mathrm{a})$; Coal Industry Nationalisation Act, 1946, 9 \& 10 GEo. 6, c. 59, $\$ 46$ (I) (a); Electricity Act, r947, 10 \& 11 GEo, 6, c. 34, \$53 (r) (a); Transport Act, 1947, ro \& II Geo. 6, c. 49, \$95(x)(a); Gas Act, I948, II \& I2 Geo. 6, c. 67, $\$ 57$ (1) (a); Iron \& Stcel

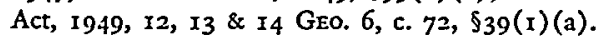


many years, but it was not until 1943 that machinery for the same purpose was established at the national level.

In 1942 the Government appointed a Board of Investigation ${ }^{2}$ under the chairmanship of Lord Greene, then Master of the Rolls, with terms of reference which included an instruction to submit recommendations for the establishment of a procedure and permanent machinery for the settlement of wages and conditions of employment in the coal mining industry. The setting up of a statutory body for this purpose however was found to be unnecessary for the reason that, as a result of discussions between representatives of the owners and of the workers, it proved possible to submit to the Board joint proposals for the establishment of national and district machinery based on the principle of collective agreement, and the Board of Investigation, impressed by the agreement of the two sides and by the practical nature of the proposals, followed them very closely in its Third Report. ${ }^{3}$ The agreement was subsequently unanimously approved by the Mining Association of Great Britain and the Mineworkers' Federation and came into operation on May 25, I943.

The National Conciliation Board set up under the agreement consisted of a Negotiating Committee and a Reference Tribunal.

The Joint National Negotiating Committee numbered twenty-two members, of whom half were nominated by the owners and half by the workmen. There were two chairmen and two secretaries; one of each being appointed by each side.

The National Reference Tribunal consisted of three permanent members, none of whom could be engaged in the coal mining industry, or (save in the case of a member of the House of Lords who held or had held high judicial office) a member of either House of Parliament.

The district conciliation agreements were modified in order to conform to a uniform basis and, in particular, to make provisions so that national questions, as well as district questions likely to affect more than one district, could be referred for determination to the Joint National Negotiating Committee or, if the Committee failed to agree, to the National Reference Tribunal set up under the national scheme. Every district conciliation agreement made provision for the appointment of a district referee to decide questions which the district conciliation board could not settle.

The agreement did not lay down procedure for settlement of questions arising at individual pits, except when they reached the stage of discussion under district conciliation agreements, but it did put an obligation on the national and district

\footnotetext{
${ }^{2}$ Appointed June 5, 1942; issued its first report on June 18, 1942. Report of THE BoARD of INvestigation into the Imisediate Wages Issue in the Coal Mining Industry (H. M. S. O., London, I942).

${ }^{3}$ Third Report of the Board of Investigation into Wages and Machinery for Determining Wages and Conditions of Employment in the Conl Mining Industry (H. M. S. O., London, Mar. I5, I943).
} 
organizations on both sides of the industry to establish better arrangements for dealing with pit disputes.

On January $\mathrm{I}, \mathrm{x} 947$ the coal mines were transferred to the National Coal Board constituted under the Coal Industry Nationalisation Act, $1946 .^{4}$

The National Union of Mineworkers (formerly the Mineworkers Federation of Great Britain) and the National Coal Board desired to adopt the national conciliation scheme, which had been in operation since I943, with such modifications as necessary to fit the new situation, and this was done by an agreement dated December 5 , 1946. The district conciliation agreements were revised. Two districts amalgamated and three others combined, but even so it was not found possible to bring the district organization of the Union into line with the divisional organization of the Board. It remained for the Board and the Union to establish uniform pit conciliation machinery.

A number of pit conciliation schemes had been established prior to the vesting date in conjunction with the district schemes. These had worked satisfactorily, but the opportunity which nationalization provided for making a comprehensive scheme for the speedy settlement of pit questions was one not to be neglected. Accordingly an agreement was made on January I, I947, under which the National Coal Board and the National Union of Mineworkers agreed to adopt a pit conciliation scheme which is now applied throughout the coal mining industry.

The principles of this scheme are:

(x) arbitration failing agreement by negotiation;

(2) speedy and efficient method of dealing with questions arising at individual pits;

(3) settlement whether by agreement or by arbitration binding on both parties and their members;

(4) district and national questions must be referred to district and national machinery respectively.

There are many questions in disputes arising at a pit, but whether they are of minor or major importance there is procedure laid down for reaching settlement.

The first stage is discussion between the workman or workmen concerned and the colliery official who allocates and supervises his work. Failing settlement, then within three days discussions take place between the workman or workmen concerned and the colliery manager or his appointed representative. If no settlement is arrived at, and the workman or workmen concerned desire to pursue the matter, the latter report immediately to the appropriate trade union official. That official has to decide whether the question is of minor importance (i.e., affecting an individual workman or a small group of workmen) or of major importance. Should he decide that the question in dispute is of a minor character, which might be settled with the manager or his representative, he proceeds to have such discussions, but if

' Coal Industry Nationalisation Act,. 1946, \$r. 
he fails to settle within three days he must carry out the procedure which would have been followed in the case of questions in dispute of major importance as set out in the following paragraph.

Immediately on receiving the report of a dispute, or upon a decision of the trade union branch to raise a question, the trade union official has to make a written request to the colliery manager, or where a question is raised by the management the colliery manager is required to make a written request to the trade union official, for a pit meeting for the purpose of discussing the question between representatives of the union and of the management. Such pit meeting must be held within five days.

If the dispute in question remains unsettled at the end of fourteen days from the date of request for a pit meeting then that dispute must be referred to the joint disputes committee.

In the event of the joint disputes committee failing to settle the question within a period of fourteen days, the joint secretaries of the district conciliation board must refer the question for decision to an umpire selected from a panel set up under the scheme.

In the first place the umpire has to satisfy himself that the question is a pit question. If in his opinion it is not a pit question he cannot decide the dispute, and it must be dealt with under the district conciliation scheme. If, however, in his opinion it is a pit question he proceeds to determine it and his decision is final.

The umpire has two assessors; one nominated by the union, and one by the management.

Thus the comprehensive conciliation machinery is in three tiers-( $\mathrm{I}$ ) national, (2) district, and (3) pit-with provision for arbitration on each tier for settling questions arising out of, or connected with, wages or conditions of employment in the coal mining industry. A "question" is defined in very wide terms and includes a part or branch of a question.

In most districts there is a panel of umpires from which the umpire to sit in any particular case may be either chosen by lot or taken in rotation. In other districts there is appointed one umpire only, to whom pit questions are referred if necessary.

The important point is that the decision in any particular case is in the hands of one umpire. This means that it is a clear cut decision. If there were, say, three umpires, majority decisions would be inevitable and such decisions might tend to lead to dissatisfaction.

Some districts prefer men of the legal profession as umpires, while others prefer men with academic or professional qualifications, or men with a knowledge of the industry. It should not be overlooked that the umpire has two assessors-one appointed by each side-to assist him, but the assessors are not allowed to vote upon or be parties to the decision.

The machinery which has been described in the preceding paragraphs covers 
about 90 per cent of the employees of the National Coal Board, but under the 1946 Act $^{5}$ the Board is required to develop conciliation machinery for all sections of its employees. There remained managerial grades, clerical staff, junior officials, foremen, and those grades in activities other than coal mining.

The managerial staff had not been members of a trade union. Their salaries and conditions of employment had been settled individually, by direct arrangements between employer and employee. It was not long however before an organization was formed to represent these grades, and in 1947 the Board granted this organization recognition for grades on a level with undermanagers and upward.

The conciliation machinery which had been established for the general body of workmen formed the model for that in respect of the managerial grades. The national arrangements were similar and the same National Reference Tribunal was appointed. Owing to the fact that prior to nationalization there was no general district basis for these grades it was more convenient to have "divisional" instend of "district" schemes. The divisions were identical with those of the Board. The model "divisional scheme" follows the same pattern as the district schemes. Schemes comparable with the pit conciliation scheme are not necessary for this staff.

As regards clerical staff, there were two unions claiming to represent them at area level and below. There was much competition between the unions for membership. Clerical workers in most districts were not organized, but in at least one district there was a collective agreement prior to nationalization.

The difficulties in the way of organization were considerable. One Association, which had agreements with the previous owners covering groups of collieries, and even individual collieries, was comprised of grades from clerk to general manager as well as technical staff. This Association was strong only in one district and had not been recognized on a district basis.

While the National Coal Board honored the agreements which existed at the vesting day it refused to give the Association national recognition in respect of any of the grades in its membership. During the latter part of 1947 this Association was merged in the British Association of Colliery Management, with which the Board later concluded the conciliation agreement for managerial grades previously mentioned.

Prior to the vesting date the Board had consulted the Trades Union Congress as to which union should represent clerks, but without success.

The two unions concerned failed to come to an agreement to act jointly, and finally the Board entered into separate negotiations on wages and hours of work with the unions.

Agreements were concluded early in 1948 . In 1949 an agreement was concluded between the Board and the Clerical and Administrative Workers' Union for clerical

${ }^{5} l d . \$ 46(\mathrm{I})(\mathrm{a})$. 
and junior administrative staff at the headquarters in London. Conciliation machinery was not established for clerical workers until April, r95I.

Officials below the rank of undermanager were a very difficult problem.

In most districts there had been a union representing mainly deputies and these district unions formed themselves into the National Association of Colliery Overmen, Deputies and Shotfirers, so that the Board was able to give national recognition to this organization in respect of deputies.

It had been the practice in a number of districts for the district unions representing deputies to take into their membership overmen and shotfirers in addition to deputies.

Other unions, however, had overmen and shotfirers in their membership. The difficulties of making agreements covering a class or grade of employee when they are in more than one union are considerable. In this case it was even more difficult as 100 per cent of the class in one district were in one union, while 100 per cent of the class in another district were in a different union. Further, there were district collective agreements, still in operation, negotiated by the different unions.

Neither union was willing to give up its members nor was it possible to effect an exchange of members so that overmen would be in one union while shotfirers would be in another.

When it became necessary to review the remuneration of these classes the Board met the unions concerned and they agreed to act jointly in respect of overmen and shotfirers. There is as yet no conciliation machinery throughout the industry for overmen, deputies, or shotfirers.

There still remained the problem of other junior officials and certain foremen grades. Their wages and terms of employment varied from colliery to colliery. The majority of them were not in a union at all and following nationalization there was much competition among the unions for their membership. Except in one district there was no union which could claim that it had negotiated and signed a district agreement covering them.

It will take some time for a satisfactory solution to be found to this problem. In the meantime their remuneration and conditions of employment were adjusted in the divisions, having regard to the need to maintain, or, as the case may be, to establish a proper relationship between their wages and the wages of other classes and the wages of those supervised by them. Those unions which had received recognition at national level were consulted at district level in respect of their members.

The National Coal Board had acquired coke and by-product plants, briquetting plants, brickworks, house property, waterworks, land, and a number of other assets which had been owned by the colliery companies or their main subsidiaries, in addition to coal industry assets. 
A considerable number of workmen were employed in these ancillary activitiesthe most important of which were coke and by-product plants.

There had been no national or district conciliation machinery for these workers prior to nationalization as there had been for mineworkers. Three unions were concerned with these workmen. One withdrew, and a working arrangement was made between the other two, under which the National Union of Mineworkers undertook to carry out negotiations on behalf of the members of both unions. Conciliation machinery for coke-oven and by-product workers was set up in 1948. Again it was based on the same lines as that for mineworkers. There are three tiers-national, district, and plant. The members appointed to the National Reference Tribunal under the national scheme are the same as in the case of the national scheme for mineworkers.

The number of men employed in briquetting plants is not large and the machinery set up for them is intended to provide in a simple form for negotiation and, if necessary, arbitration on matters relating to wages and conditions of employment. There are three unions concerned and they have agreed to act jointly. At the national level there is a National Joint Council numbering sixteen members, half of whom are appointed by the Board and the other half by the unions. The Council acts by agreement between the two sides, each side acting by a simple majority. The procedure for settling disputes is entirely different from the coal mining scheme. In the event of failure to agree, the question in dispute is referred to a form of arbitration to be agreed upon by both sides, and if such agreement is not reached, then the dispute is to be referred to the Ministry of Labour and National Service, with a view to intervention by a conciliator. If this procedure fails, either side of the National Council can request that the question be referred to the Industrial Court appointed under the Industrial Courts Act $19 \times 9 .^{\text {sa }}$

The scheme provides for the establishment at each plant of a procedure for dealing with plant questions. No uniform arrangement has been laid down in view of the comparatively small number of employees at the plants, and it has been left to the representatives of both sides in each division to establish a conciliation procedure which will best suit the individual plants in each division, but it must provide certain essentials laid down in the national scheme, viz: any question under dispute which involves the interpretation of a national agreement must be referred to the national machinery, and any other question which cannot be settled at the plant must be referred for negotiation between the management and the trade union representatives. If they fail to settle, the matter has to be referred to a form of arbitration to be agreed between representatives of the Board and of the unions.

More than half of the workmen are employed at plants in one division, and for this reason provision was made for the establishment of a divisional scheme if the National Council deemed it necessary. A conciliation board with similar procedure

\footnotetext{
5n 9 \& 10 Geo. 5, c. 69.
} 
to that of the National Council was set up in the division concerned. If the conciliation board fails to reach a settlement the matter has to be referred to a form of arbitration, to be agreed between representatives of the Board and the unions.

In the transport, electricity supply, and gas industries the conciliation machinery which existed prior to nationalization was continued, and the problems which the National Coal Board had as regards unions were not so considerable.

There is no doubt that nationalization offered a great opportunity to the trade unions. Men who formerly had not felt it necessary to be members of a trade union began to think that it was desirable to join. No doubt this was inevitable as many felt that the personal touch had gone.

In the past if a man felt aggrieved he could leave one employer and find employment with another in the same industry. Under nationalization he cannot find another employer in the same industry as there is only one.

In theory there should be no stoppages through disputes at all, but in fact in the coal mining industry there were about $\mathrm{x}, 600$ stoppages in each of the years 1947 to $1950^{\circ}{ }^{6}$

These could have been avoided if the workmen had used the conciliation machinery.

It is extremely important that both sides should strictly adhere to the constitutional machinery. Any reluctance to do so by either side undermines confidence. It may be said that all the strikes were unofficial; they were not backed by the union. Most of them were small, and could only mean delay in reaching a settlement, as the Board could not negotiate until work was resumed. The Board is responsible for seeing that the conciliation machinery is understood by its representatives wherever they may be, but the union also has a responsibility in making the working of the machinery known to its members through the districts, the branches, and the lodges, as well as disciplining its members to honor awards or decisions made at any stage as final and binding. The pit scheme is perhaps the most important part of the machinery and its success depends on the confidence which both sides have in each other and in the justice of the scheme.

There was one attempt by discontented and breakaway elements to evade agreements to which they had been parties. A section of one class of workmen, viz., winding enginemen, broke away from the National Union of Mineworkers because they felt that their interests were not adequately represented. A new union was formed for winding enginemen and this union claimed the right to be recognized by the National Coal Board as representing winding enginemen at the national level. The Board could not negotiate with an organization outside the conciliation machinery, which already provided for winding enginemen, without undermining the established machinery and making it completely ineffective. In July 1949 the

\footnotetext{
- National Coal Board Reports and Accounts 35, par. i68 (i948); id. at 81, par. 31 i (1949); id. at 51, par. 233 (1950).
} 
breakaway union reported to the Minister of Labour that a dispute existed between them and the Board. The dispute was referred to the National Arbitration Tribunal-a body set up under the Conditions of Employment and National Arbitration Order No. 1305 of I940-and, on the question of recognition, the National Arbitration Tribunal ${ }^{7}$ endorsed the finding ${ }^{8}$ of a previous Court of Inquiry that the wages and conditions of winding enginemen should be settled by means of the conciliation machinery set up by agreement between the Board and the National Union of Mineworkers. It would seem that this matter is one of internal organization of the union and it is to be hoped that the union, realizing the fundamental principle which is at stake, will be able to arrive at a solution satisfactory to all winding enginemen.

\section{III}

\section{Negotration}

In order to understand the wage position in the various coalfields on January I, 1947, when the coal mining industry was transferred to public ownership, it is necessary to give a brief summary of past arrangements.

For many years wages had been regulated by separate agreements negotiated in the twenty-one districts into which the coal mining industry was divided for this purpose.

While there were some conditions of employment, other than wages, operating in a district which were also covered by a district agreement, there were others, such as coal allowances, which were often governed by agreements at an individual colliery or group of collieries. An astonishing number of variations are to be found in these colliery agreements relating to the supply of coal to miners as regards quantity, price (if any), and conditions attaching to the concession.

The basis rates for the various classes of workmen on day wages were determined in each district and these operated as minimum rates. The basis rates for pieceworkers were settled at the individual collieries in order that the local physical conditions and methods of work could be taken into account.

The district agreements provided that the percentage addition to basis rates in any given period should be calculated by applying a formula to the results of colliery working in a past period. Thus, for example, the percentage addition to basis rates in March might be based on the results in January, that in April on the results in February, and so on.

The formula was based on the principle, which was common to all districts, of sharing in agreed proportions the "surplus proceeds" (i.e., the difference between proceeds and costs other than wages) between wages and profits. The ratio between

\footnotetext{
${ }^{7}$ National Arbitration Tribunal Award No. 1340, issued on Oct. xo, 1949.

${ }^{8}$ Report of a Court of Inguiry (constituted by the Ministry of Labour and National. Service under the INdustrial Courts Act, igrg) into a dispute between the National Coal BoArd and thiE Nattonal Union of Colliery Winding Enginemen (Jan. 24, 1948).
} 
wages and profits was $85: 15$ in most districts and although it was slightly different in a few districts the average over the country as a whole was approximately 85:15. It is necessary to add, however, that each district agreement laid down a certain minimum percentage addition to basis rates below which the level of wages could not fall.

Under these ascertainments the wages payable in each district therefore varied according to the capacity of the district to pay except in those districts where the results of colliery working were such that the wages payable were at the minimum percentage addition to basis rates provided by the district agreement.

In March $194^{\circ}$ a national agreement was made under which it was agreed that the district wage arrangements should continue to operate during the war, subject to mutually agreed alterations, but increases of wages necessary to take account of the special conditions arising out of the war, and particularly the increased cost of living, should be dealt with on a national basis by means of uniform flat-rate additions. The flat-rate additions were determined by a formula based on the cost of living index figure published by the Ministry of Labour. ${ }^{9}$ The cost of these additions was deducted from the balance available for wages in each district thus reducing pro tanto the percentage addition to basis rates payable in those districts which were paying wages above the minimum. The effect, therefore, was to increase only the minimum wages payable, by the amount of the flat-rate addition.

Circumstances arose during the war which made it imperative, in order to preserve peace in the industry, to grant further increases on a national basis by way of flat rates, all of which were treated in the district ascertainments in the same way as the first war advance which varied according to the formula based on the cost of living index figure.

In May 194I the Essential Work (Coalmining Industry) Order ${ }^{10}$ came into operation. This Order provided for the payment of a guaranteed wage, in respect of every week, to every workman who during his normal working hours was (a) capable of and available for work, and (b) willing to perform reasonable alternative work when his own work was not available for him.

In June 1942 as the result of the Report of the Board of Investigation into the Wages of the Coal Mining Industry ${ }^{11}$ the principle of a national minimum weekly wage was accepted and minimum weekly wages, which included the value of allowances in kind, were fixed for adult underground and adult surface workers respectively. Later national minimum weekly wages for those under 2I years of age were granted by awards of the National Reference Tribunal and the minimum weekly

${ }^{\circ}$ Cost of living index figure (July, $\mathrm{x}_{914}=\mathrm{zo0}$ ), published monthly in the Ministry of Labour Gazette. The figure was discontinued in June, I947.

${ }^{10}$ S. R. \& O., 1941, No. 707; amended by S. R. \& O., 1941, No. 2008; 194I, No. 2096; id., 1942, No. I $847 ; 1943$, No. I80; and 1943 , No. 505 .

iI Report of the Board of Investigation into the Immediate Wages Issue in the Coat Mintig INDUSTRY, op. cit. stpra, note 2. 
wages for adults were increased. These latter, by telescoping the lower rates then operating, resulted in a serious disturbance of the relativity of the wage scale in many districts. The unrest which this caused was so serious that the owners and workers commenced negotiations in the various districts with a view to granting increases to iron out the anomalies which had been created.

The Government, however, stopped these negotiations and put forward to both sides of the industry certain proposals for the stabilization of wages other than changes due to the cost of living. These proposals were ultimately embodied in an agreement made between the Mining Association of Great Britain and the Mineworkers Federation of Great Britain in April 1944. This agreement suspended the district ascertainments for the duration of the agreement. It also provided that during the currency of the agreement no variation would be sought by the parties in the rates awarded in the existing operative awards of the National Reference Tribunal or district conciliation machinery or in district rates as modified by the agreement. Further, no application for alterations in wage rates at a pit could be made other than those normally made in respect of changed methods or conditions of working in accordance with custom or agreement existing in the district. In short, it stabilized wages for a period of at least four years as the agreement could not be terminated before June 30, 1948 .

It was not surprising, in view of what has been said, that in January 1947 wages in the various districts ranged over a considerable scale with the highest wages being paid in those districts which were the most profitable.

Agreements made between the National Union of Mineworkers and the Mining Association of Great Britain, and between constituent associations of the National Union of Mineworkers (formerly the Mineworkers Federation of Great Britain) and associations of employers, and settlements made under the established conciliation machinery were carried over by the Board on January I, I947 subject to an important modification of the April 1944 agreement.

The modification raised the ban on seeking alterations in the rates awarded by the National Reference Tribunal and enabled the Board and the Union to enter into national agreements on wages. It also allowed applications for alterations in wage rates at a pit to be made after a period of six months following the establishment of pit conciliation machinery. This machinery was established on January $\mathbf{~ ,}$ 1947 and so applications for alterations in wage rates at a pit could be made as from July $x$, I947.

The way was now open for negotiation on a national basis. The National Union of Mineworkers pressed strongly for the introduction of a five-day week. Early in '1946, discussions about the possibilities of the five-day week had taken place between representatives of the Union and the Ministry of Fuel and Power with the result that the Minister of Fuel and Power announced in the House of Commons in June 
$194^{12}$ that the Government had no objection to its introduction provided that it was properly organized and the country's needs of coal were met.

The Reid Report ${ }^{13}$ had recommended that there was a strong case for introducing a five-day week of eight hours a day (i.e., an increase of half an hour per day).

The National Coal Board decided that negotiations should be commenced soon after the vesting date (i.e., January I, I947) on the conditions which should be applied in a five-day week so that the output which the country needed would be forthcoming. The claim of the Union was that while there should be a reduction in the normal working week to five days there should be no reduction in wages. After long negotiations it was finally agreed that the five-day week should commence on May 5, 1947. The agreement ${ }^{14}$ provided for the working of five full shifts of $7 \frac{1}{2}$ hours plus one winding time ${ }^{15}$ for underground workers. This meant no increase in the length of the shift except at some collieries where it had been customary to work shorter hours on certain afternoon or night shifts.

As regards surface workers, the normal working week became one of $42^{1} \frac{1}{2}$ hours (exclusive of mealtimes) in five full shifts of $8 \frac{1}{2}$ hours except that if under an existing district agreement the normal working week had been less than $42^{1 / 2}$ hours then that should continue spread over five days.

The hours of surface workers previously had varied considerably, not only in respect of the normal week but also daily. Those manipulating coal on the surface had often worked different hours from other surface workers as their work was geared to production. On the average it meant a considerable reduction in weekly hours although certain workmen had to work a little longer on each of the five days.

In order to get the output which was needed it was necessary to increase the weekly output and accordingly it was provided that there should be a reassessment of tasks on the basis of a fair day's work for each man concerned. It had previously been the practice at certain collieries for workmen to leave the pit before the end of the shift if their task had been completed, but with a five-day week customs such as this had to be abandoned. The response on the whole was disappointing.

The question of wages was exceedingly difficult. Some workmen had worked six shifts per week, others six and five in alternate weeks, while others had worked various combinations of six and five, and some only five per week. Finally it was agreed that a workman who worked his five full normal shifts should receive a bonus.

${ }^{12} 424$ H. C. DEB. I322, 1325 (5th ser. 1946).

1. Report of the Technical Advisory Committee on Conz Mining (Mar. 1945), CMd. No. 661o (I945).

i4 National Coal Bonrd Annual Report and Statement of Accounts for the Year Ended DeCEMBER 3I, I947, 197-200, App. IV (1948).

15. "Winding time" is the time spent either in lowering the whole of a shift of workmen into the pit or raising them again. The winding time in Great Britain averaged over the whole of the collieries is about half an hour. The hours underground bank to bank are therefore about eight hours per shift. The average working time at the coal face (less breaks) is about $61 / 4$ hours per shift. 
In the case of a workman paid a daily wage the amount of the bonus was his average day wage while in the case of the pieceworker it was 16 per cent of his earnings in his five shifts. The bonus is conditional on attendance throughout the five full shifts.

Any work performed outside the normal working week was paid at overtime rates. The "weekend" period was increased from three to four shifts. The overtime rates were increased from time-and-a-third to time-and-a-half while weekend rates were increased from time-and-a-half to double time. The net result was an increase in wages which fell unevenly not only on various districts but on certain workmen at collieries within a district. Some workmen on the minimum received no increase at all in their wages for a normal working week. The wage structure had become even more complicated.

This was an agreement which was bound to cut across some district or local customs but they had to go if the national agreement was to be maintained. Diffculties arose over increasing the tasks, adjusting the hours of certain grades of surface workers, and many other matters. While all these should have been settled by means of the established conciliation machinery, unfortunately there were stoppages resulting in a loss of 800,000 tons. ${ }^{16}$

It soon became clear that the output needed would not be obtained and after long negotiations a settlement was reached providing for organized overtime working of either (I) a sixth shift which might be shorter than a normal shift but in no case less than $61 / 2$ hours plus one winding time for underground workers, or (2) an extra half-hour per day on each of the five normal shifts, or (3) both (I) and (2) having regard to local circumstances. Arrangements were accordingly made in the divisions in the early part of November 1947. The agreement terminated on April 30, I948 but was then renewed for a period of twelve months. Further annual renewals were made in April 1949 and April 1950.

The provisions of the five-day week agreement, however, continued to operate. The extra hours worked whether on each day or by means of an additional shift were paid for at the appropriate overtime rate.

The Reid Report ${ }^{17}$ had stressed that one of the advantages of the five-day week was that it left the weekend free for repair and maintenance work. That advantage has been lost for the reason that with few exceptions the "organized overtime" has been worked by way of a sixth shift at the weekend.

In October 1947 the National Union of Mineworkers submitted a claim for a general increase in the wages of underground and surface workers. The Board however took the view that a general increase could not be justified, but that they would consider the wages of the lower paid workers. After further negotiations it

\footnotetext{
${ }^{10}$ National Coal Board Annual Report and Statentent of Accounts for the Year Ended DeCENrBER 3r, 1947, op. cit. stppra note 14 , at $\times 7$, par. 7I.

${ }^{17}$ Report of the Technical Advisori Commitie ox Coal Misisig, op. cit. sippra note 13, at 125, par. 743 .
} 
was agreed that the minimum weekly wages should be increased to $f_{0} 5.15 .0$. for adult underground workers and to $f_{5}$.0.0. for adult surface workers. The minimum wages for those under $2 \mathrm{r}$ were increased proportionately. Day-wagemen received increases of up to $2 / 6 \mathrm{~d}$. per shift (underground) or I/8d. per shift (surface) provided that the revised rates did not exceed fixed "ceilings."

The result was that while the men in lower paid districts with high costs and with little or no profit received substantial increases many of those in the higher paid districts with low costs and high profits received little or no advance.

It was however loyally accepted in the latter districts but how far this kind of agreement will be accepted in the future is doubtful.

It is impossible to raise every district up to the highest. The cost would be prohibitive. The answer must be to reduce costs by increasing productivity per man in the high cost districts. Natural conditions may be a factor working against this and while the costs may never be reduced to the low level of some districts there is room for a substantial increase in output per man, per shift and per annum, which would result in substantial savings in costs. It seems clear that a simplified wage structure can only be developed gradually. The first step towards this end was made in June 1948 when an agreement was signed on the classification, grading, and rates of wages of craftsmen who represent about 5 per cent of the workers employed in the industry.

One or two district agreements had classified craftsmen and graded them but in most district agreements tradesmen were only classified according to their trade without any grading.

The district rates were often not the same for all trades. In a few districts there were no district rates for these classes in existence; the rates had been determined at individual collieries according to local circumstances. The result was that prior to the national agreement of June 1948 the variation in rates payable to craftsmen was considerable. This agreement scheduled those classes of workmen to be regarded as skilled craftsmen. It provided for two grades, namely, Grade I (fully skilled) and Grade II (others).

It was a difficult task to classify and grade the workmen colliery by colliery but, with goodwill on both sides, the appropriate representatives of the Board and the union in each of the divisions completed it before the end of year, except in one division where agreement was finally reached early in 1949 .

A number of other national agreements have been made, e.g., wages for certain grades and holidays with pay, but one agreement providing for the deduction of union contributions from the wages of the union's members is of particular interest. It was only concluded after prolonged negotiations.

When the request for the deduction of union contributions was made to the Board by the National Union of Mineworkers at the beginning of 1948, the Union 
stated that they desired a national agreement which would provide that membership of the Union should be a condition of employment.

Immediately prior to nationalization in some districts this had been a condition of employment but in others no such condition had been imposed although it was understood that colliery officials would encourage workmen to join a union.

To grant the request would have meant a "closed shop" and those workmen who did not join a union would have to be dismissed. As there was now only one employer for the whole industry the workmen would not only be dismissed from their job but from the industry. Further, if the union expelled a workman from membership, the Board would be compelled to dismiss him although in all other respects he was a satisfactory employee.

The Board refused to enter into such an agreement but agreed to a procedure for the deduction of trade union contributions which came into operation in the majority of districts early in 1949.

It is of interest to note that in at least one district the local union has not asked the division to put this practice into operation. The individual continues to pay his union dues to the branch treasurer and presumably the local union feels that this method retains a closer contact with its members.

In October I950 the national weekly minimum for adult workers was increased by $5 /-$ per week to $£ 5.5 .0$ for surface workers and $£_{6} 6.0 .0$. for underground workers. These minima however include the value of allowances in kind. The allowances in kind are free houses or rent allowances in lieu thereof and free or cheap coal. The value agreed in the various districts for this purpose however is only a nominal one representing a third or even less of the real value.

This is a very real difficulty in the way of revising the wage structure. The unions have rejected an offer by the Board to pool the total tonnage and receipts of miners' coal and share the pool in a uniform manner to be agreed.

It had been proposed that the quantity, the price, and conditions of entitlement should be governed in the future by a national agreement on miners' coal superseding all existing pit or district agreements.

The most the Union offered to do was to endeavour to persuade those districts, where workmen received more than a certain minimum quantity, to give up a small portion of their entitlement for workmen in two districts where it had not been the practice to grant miners' coal. The Union, however, could not get the support of the workmen in those districts which would have to contribute and accordingly the scheme had to be abandoned.

Many of the existing pit or district agreements on the supply of miners' coal were made many years before the advent of pithead baths, and in many cases today the quantities to which the recipients are entitled are far in excess of what would be needed for ordinary requirements. In some districts there are agreements under 
which tonnage not taken can be sold back to the colliery at a price not much less than the pithead price.

The problem has been tackled in Scotland with partial success in that agreement has been reached on quantity per annum. Those entitled to coal at collieries with pithead baths will receive less than those at collieries without pithead baths.

It would seem clear that agreements in all divisions on these lines at least are long overdue, but there is no doubt that it would be beneficial in the long run to have a national agreement regulating the supply of miners' coal even if, as a first step, it was only on the principles to be applied.

As time goes on this question will assume more importance in view of the contemplated transfers of workmen from one colliery to another. Further, more and more collieries are being equipped with pithead baths and the difficulty of reaching a solution will then increase.

It is an important matter from the point of view of labor relations. The anomalies are considerable and no strong case can be made out to justify them, bearing in mind particularly that there is only one employer.

It is clearly unsatisfactory for the wages and conditions of employment of workmen to be governed by so many different agreements.

National agreements which have to be superimposed on district agreements are liable to appear unnecessarily complicated to workmen in a particular district for the reason that certain items which are mentioned to cover the position in other districts have no meaning at all in that particular district. The agreements which have been made by the Board have lessened the wide differences which existed in rates of wages by day-wagemen as between districts.

From the point of view of labor relations the maintenance of the relationship between the rates of wages of the various classes of workmen at a colliery and in the same district is extremely important. The trouble is that these relationships are not the same in each district and since nationalization there has been a tendency, not only on the part of the unions, but also on the part of the workmen, to look rather more at the position of similar classes of workmen in other districts with the result that dissatisfaction ensues.

IV

\section{Consultation}

The various acts by which certain industries were placed under public ownership imposed an obligation on the management, ${ }^{18}$ except in those cases where satisfactory machinery was already operating, to enter into consultation with the appropriate organizations representing the workmen in order to establish and maintain machinery for joint consultation on questions relating to the safety, health,

${ }^{18}$ Civil Aviation Act, $1946, \S \mathrm{Ig}(\mathrm{I})(\mathrm{b})$; Coal Industry Nationalisation Act, $1946, \$ 46(\mathrm{I})(\mathrm{b})$; Electricity Act, $1947, \S 53(\mathrm{I})(\mathrm{b})$; Transport Act, I947, $\$ 95(\mathrm{I})(\mathrm{b})$; Gas Act, 1948, $\$ 57(\mathrm{r})(\mathrm{b})$; Iron and Steel Act, $1949, \$_{39}(\mathrm{r})(\mathrm{b})$. 
and welfare of employees and on the organization and conduct of the operations in the industry and also on other matters of mutual interest.

As regards safety and health it should be emphasized that the human factor is all important. If common agreement can be achieved on measures to prevent accidents and to safeguard health there is more chance of success. A good consultative committee can do much in this direction and raise the standard of self-discipline on the part of the workmen themselves in complying with safety regulations and local rules.

In the coal mining industry consultative machinery has been set up at all levelsnational, divisional, area, and colliery. The Chairman of the National Coal Board is Chairman of the National Consultative Council, the divisional chairman of the divisional council, the area general manager of the area council, and the colliery manager of the colliery consultative committee.

Questions relating to wages, terms and conditions of employment, and other matters which are properly the subject of negotiations between organizations of employers and workmen under the conciliation machinery are excluded from the scope of the consultative machinery.

At the colliery level experience has varied. Some committees have been very successful, others, however, have failed either owing to lack of leadership from the management or to insufficient support from the workmen.

A better understanding of consultation will no doubt develop in time. It is important that it should have the backing of the union at all levels as, without this, success is impossible.

The Board's plan for the future development of the coalfields involves the closing down of a number of uneconomic collieries, the reorganization or reconstruction of others in whole or in part, and the sinking of new pits. Inevitably this will mean that some workmen will be surplus to requirements but the great majority will be found jobs at other collieries. In some districts it will mean the transfer of workmen to collieries many miles away. The housing and social problems will be considerable.

In such matters as these it is vital that there should be the fullest consultation with the appropriate unions as only with the cooperation of the workmen can the best possible results flow from these plans.

\section{$\mathrm{V}$}

\section{Conczusion}

Complete conciliation machinery has been established for over 90 per cent of the employees in the industry but that in itself is only the beginning. The Board and the appropriate trade unions have shown their faith in it. So have many of the workmen but there are still some who resort to strike action (not backed by the unions) which can only produce negative results as negotiations cannot proceed until work is resumed. It is the responsibility of the unions to see that their members fully understand the agreed procedure for settling disputes. 
As regards negotiation the unions have made it clear that they desire national agreements, but so far there has been little sign that they have appreciated that many local or district customs cannot be perpetuated under such arrangements. It would seem that some of those customs will have to go.

Another point which would seem worth consideration is the desirability of consolidating many of the existing agreements. No doubt workmen who have been in the industry for many years understand which agreements, or parts of agreements, governing their wages and conditions of employment apply to them. On the other hand new entrants must find the position extremely complicated. Questions frequently arise as to which agreement is to prevail on a particular point.

Improvements in the wage structure will have to be developed gradually but the unions themselves have a responsibility in this matter and they could make a useful contribution to this end.

Joint consultation exists for improvements in production, health, safety, and welfare under which a workman can feel that he is playing his part in the more efficient performance of his work and is making his contribution to the solution of problems affecting his own colliery and the industry as a whole.

The machinery which has been set up for the purpose of creating good labor relations is not in itself sufficient. It is the spirit which counts and that will be fostered only by inspired and sympathetic leadership. 